\title{
Pincer nails: an initial and isolated cutaneous manifestation of systemic lupus erythematosus
}

\author{
Paznokcie pincetowate - początkowy i izolowany objaw skórny tocznia \\ rumieniowatego układowego
}

Manoj Karbhari Pawar

MVP's Dr.V.P Medical College \& Hospital, Nashik, India

MVP's Dr.V.P Medical College \& Hospital, Nashik, Indie

CORRESPONDING AUTHOR/ ADRES DO KORESPONDECJI: Manoj Karbhari Pawar MVP's Dr.V.P

Medical College \& Hospital Nashik, India

Phone: +91 7447439800

E-mail:

manojpawar624@yahoo.com

\begin{abstract}
Introduction. Pincer nail deformity due to systemic lupus erythematosus is a rare phenomenon and only three cases have been reported to date.

Objective. To present a case of pincer nails in a systemic lupus erythematosus patient and a brief review of the literature.

Case report. A 15-year-old girl presented with multiple painful pincer nail deformities, fever and joint pain of 6 months duration. On evaluation and laboratory investigations the patient fulfilled the criteria for systemic lupus erythematosus. Systemic treatment with glucocorticosteroids and antimalarials led to resolution of fever and joint pain but nail deformities did not improve.
\end{abstract}

Conclusions. Pincer nail may be an early and important sign of systemic lupus erythematosus in certain patients.

\section{STRESZCZENIE}

Wprowadzenie. Deformacja w postaci paznokci pincetowatych $\mathrm{w}$ przebiegu tocznia rumieniowatego układowego jest zjawiskiem rzadkim. Dotychczas w piśmiennictwie odnotowano zaledwie trzy takie przypadki.

Cel pracy. Przedstawienie przypadku paznokci pincetowatych u pacjentki z toczniem rumieniowatym układowym oraz krótki przegląd piśmiennictwa.

Opis przypadku. Piętnastoletnia pacjentka zgłosiła się z licznymi bolesnymi zniekształceniami w postaci paznokci pincetowatych, gorączką oraz bólami stawowymi, które utrzymywały się od 6 miesięcy. Badanie przedmiotowe i wyniki badań laboratoryjnych były zgodne z kryteriami diagnostycznymi tocznia rumieniowatego układowego. Po wdrożeniu leczenia ogólnoustrojowego glikokortykosteroidami i lekami przeciwmalarycznymi gorączka i ból stawów ustąpiły, jednak nie uzyskano poprawy stanu paznokci.

Wnioski. Paznokcie pincetowate mogą być wczesnym i istotnym objawem tocznia rumieniowatego układowego u niektórych pacjentów.

Key words: antimalarials, pincer nails, prednisolone, systemic lupus erythematosus.

Słowa kluczowe: leki przeciwmalaryczne, paznokcie pincetowate, prednizolon, toczeń rumieniowaty układowy. 


\section{INTRODUCTION}

Pincer nail (also known as omega nail, trumpet nail, convoluted nail, and unguis constringens) is the transverse over-curvature which progressively pinches the nail bed distally $[1,2]$. It increases in a proximal to distal direction, giving a trumpet appearance. It is more commonly observed on toes than on fingers [2]. It can be hereditary or acquired. An ill-fitting shoe is the most frequent acquired cause [3]. Different dermatoses, such as psoriasis (the most common dermatologic cause), tumors of the nail apparatus and tinea unguium can lead to pincer nail deformity $[4,5]$. Systemic diseases, placement of arteriovenous fistula (AVF) and use of medications, i.e. $\beta$-blockers such as practolol and acebutolol, can lead to pincer nail deformity [6-12]. Pincer nails associated with systemic lupus erythematosus (SLE) were described in 2005 [13], in 2016 [14] and recently in January, 2017 [15]; but to our knowledge, an isolated finding of pincer nails as the only presenting cutaneous manifestation of SLE has not been reported.

\section{CASE REPORT}

A 15-year-old girl born of non-consanguineous marriage presented with progressive, symmetric blackish discoloration and deformities of multiple finger and toe nails of 6 months duration, associated with debilitating subungual pain and tenderness, interfering with her daily activities. It was not associated with bleeding or oozing from the affected nails. There was no history of similar episodes or trauma before the onset of these deformities. She denied usage of any ill-fitting shoes. Family history was negative for similar complaints. The patient also complained of general body malaise, low grade, intermittent fever without cough and chills, but associated with moderate pain in both elbow and wrist joints, which was continuous in nature and did not improve after activity. For these complaints the patient consulted a local physician and was treated with nonsteroidal anti-inflammatory drugs, resulting only in symptomatic relief. There was no history of photosensitivity, oral ulcers, dyspnea on exertion, swelling of periorbital area, edema or conjunctival congestion. She did not complain of weight loss, vomiting, abdominal pain or blood in the stool. She did not take any drug, other than prescribed by her treating physician. There was no history of any major skin or systemic diseases.

When the patient came to us, examination revealed diffuse hyperpigmented, pincer nails of multiple fingers and toes with onychogryphosis

\section{WPROWADZENIE}

Paznokcie pincetowate (omega nail, trumpet nail, convoluted nail, and unguis constringens) to schorzenie polegające na nadmiernym poprzecznym zawijaniu się płytki paznokciowej, które powoduje stopniowe dystalne zakleszczanie łożyska paznokcia [1, 2]. Przerost nasila się od strony proksymalnej do dystalnej, a paznokieć kształtem przypomina rurkę. Choroba częściej dotyczy paznokci stóp niż rąk [2]. Paznokcie pincetowate mogą mieć charakter dziedziczny lub nabyty. Najczęstszą przyczyną w przypadkach nabytych jest źle dopasowane obuwie [3]. Paznokcie pincetowate mogą się również pojawiać w przebiegu różnych dermatoz, m.in. łuszczycy (najczęstsza przyczyna dermatologiczna), a także nowotworów aparatu paznokciowego oraz grzybicy paznokci [4, 5]. Wśród innych przyczyn paznokci pincetowatych wymienia się choroby układowe, wytworzenie przetoki tętniczo-żylnej (arteriovenous fistula - AVF) oraz stosowanie niektórych leków, m.in. $\beta$-adrenolityków (praktolol, acebutolol) [6-12]. Przypadki paznokci pincetowatych $\mathrm{w}$ przebiegu tocznia rumieniowatego układowego (systemic lupus erythematosus - SLE) opisano w latach 2005 [13] i 2016 [14] oraz ostatnio - w styczniu 2017 r. [15], jednak według naszej wiedzy w piśmiennictwie nie ma doniesień dotyczących występowania paznokci pincetowatych jako jedynego skórnego objawu SLE.

\section{OPIS PRZYPADKU}

Piętnastoletnia dziewczynka urodzona w małżeństwie osób niespokrewnionych, zgłosiła się z postępującymi, symetrycznie rozmieszczonymi, ciemnymi przebarwieniami i zniekształceniami wielu paznokci rąk oraz stóp. Utrzymującym się od 6 miesięcy zmianom towarzyszyły uniemożliwiające funkcjonowanie ból i tkliwość. Nie występowało krwawienie ani wysięk wydzieliny spod zmienionych paznokci. W wywiadzie nie stwierdzono podobnych epizodów i urazów poprzedzających wystąpienie objawów. Pacjentka nie nosiła źle dopasowanego obuwia. Podobnych przypadków nie było w wywiadzie rodzinnym. Pacjentka zgłaszała również ogólne złe samopoczucie, sporadyczne występowanie stanów podgorączkowych bez towarzyszącego kaszlu i dreszczy, a także ból o umiarkowanym nasileniu w stawach łokciowych i nadgarstkowych. Ból miał charakter ciągły i nie ustępował po aktywności fizycznej. Z powyższymi objawami pacjentka zgłosiła się do miejscowego lekarza, który zalecił niesteroidowe leki przeciwzapalne. Terapia przyniosła jedynie złagodzenie objawów. W wywiadzie nie stwierdzono nadwrażliwości na światło, owrzodzeń jamy ustnej, duszności wysiłkowej, obrzęku wokół oczodołów, innych obrzęków i przekrwienia spojówek. Nie występowała również utrata masy ciała, wymioty, bóle brzucha oraz 
of both thumbs and distal dystrophy of both great toes (Figs. 1 and 2). There were no muco-cutaneous lesions noted and hairs was normal too. Peripheral pulses were equal, regular in rhythm and adequate in volume. Systemic examination did not reveal lymphadenopathy, organomegaly or any significant finding.

Potassium hydroxide preparation, fungal culture and periodic acid-Schiff staining from the nail clipping revealed no fungal growth. The laboratory tests revealed leucopenia of 3,300 cells $/ \mathrm{mm}^{3}$, thrombocytopenia of 1,20,000 per $\mathrm{mm}^{3}$, hemoglobin $9.4 \mathrm{~g} / \mathrm{dl}$ and erythrocyte sedimentation rate (ESR) of $85 \mathrm{~mm} / \mathrm{h}$. Meanwhile, an immunologic panel revealed positive ANA (end point titer of $1: 2560$ ) in a homogeneous pattern, anti-dsDNA antibodies (end point titer of $1: 160$ ) with positivity to anti-nucleosome antibodies and anti-AMA-M2 antibody. Other laboratory investigations including chest and joints X-rays and abdominal ultrasound revealed no abnormality. In this patient, SLE diagnostic criteria were fulfilled when leucopenia and two positive immunological findings were present additionally to the patient's clinical features of non-erosive arthritis, fever and malaise. After thorough evaluation and ophthalmologic examination she was prescribed a high dose of oral prednisolone at an initial dose of $1 \mathrm{mg} / \mathrm{kg} /$ day, which was gradually tapered, and oral hydroxychloroquine $200 \mathrm{mg} /$ day was added thereafter. For nail deformities and pain, along with the anti-inflammatory drug, 20\%

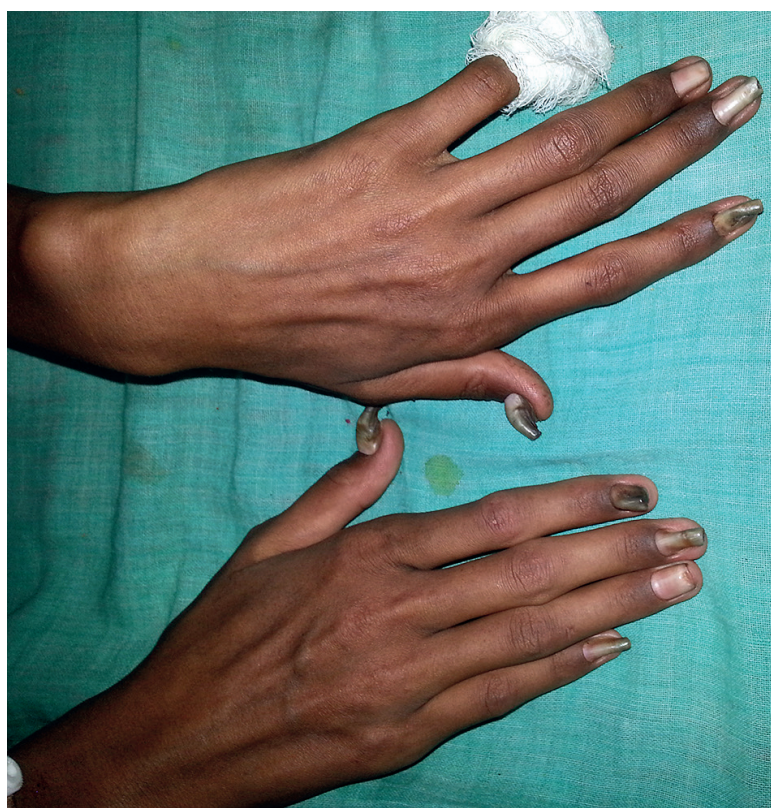

Figure I. Pincer nails: multiple hyperpigmented, pincer nails (sparing ring fingers) with onychogryphosis of both thumbs

Rycina I. Paznokcie pincetowate - liczne paznokcie pincetowate (z wyjątkiem palców serdecznych) z widocznymi przebarwieniami oraz szponowatościq obu kciuków krew w stolcu. Pacjentka nie przyjmowała żadnych leków poza środkami przepisanymi przez lekarza prowadzącego leczenie. Nie przebyła żadnej poważnej choroby skóry ani chorób układowych.

W badaniu przeprowadzonym po zgłoszeniu się pacjentki do naszego ośrodka stwierdzono liczne paznokcie pincetowate zarówno rąk, jak i stóp, z obecnością rozlanych przebarwień, a także szponowatość obu kciuków i dystalną dystrofię obu paluchów (ryc. 1 i 2). Nie stwierdzono zmian skórno-śluzówkowych ani nieprawidłowości w obrębie włosów. Badanie ogólne nie ujawniło powiększenia węzłów chłonnych, powiększenia narządów oraz innych istotnych nieprawidłowości.

Bezpośrednie badanie mykologiczne oraz posiew nie potwierdziły zakażenia grzybiczego. Badania laboratoryjne wykazały leukopenię (3300 komórek/ mm³), małopłytkowość $\left(120\right.$ 000/ $\left.\mathrm{mm}^{3}\right)$, stężenie hemoglobiny 9,4 g/dl oraz OB $85 \mathrm{~mm}$. W ramach panelu badań immunologicznych stwierdzono dodatnie miano przeciwciał ANA (miano końcowe 1 : 2560) o jednorodnym rozkładzie, przeciwciała anty-dsDNA (miano końcowe 1 : 160) z dodatnimi przeciwciałami przeciwko nukleosomom i przeciwciałami anty-AMA-M2. Nie wykazano nieprawidłowości w badaniu rentgenowskim klatki piersiowej i stawów oraz badaniu ultrasonograficznym jamy brzusznej. U pacjentki spełnione były kryteria diagnostyczne SLE: leukopenia i dwa dodatnie oznaczenia immunologiczne w skojarzeniu z objawami klinicznymi (nienadżerkowym zapaleniem stawów, gorączką i złym samopoczuciem). Po przeprowadzeniu dokładnych badań i oceny okulistycznej pacjentce

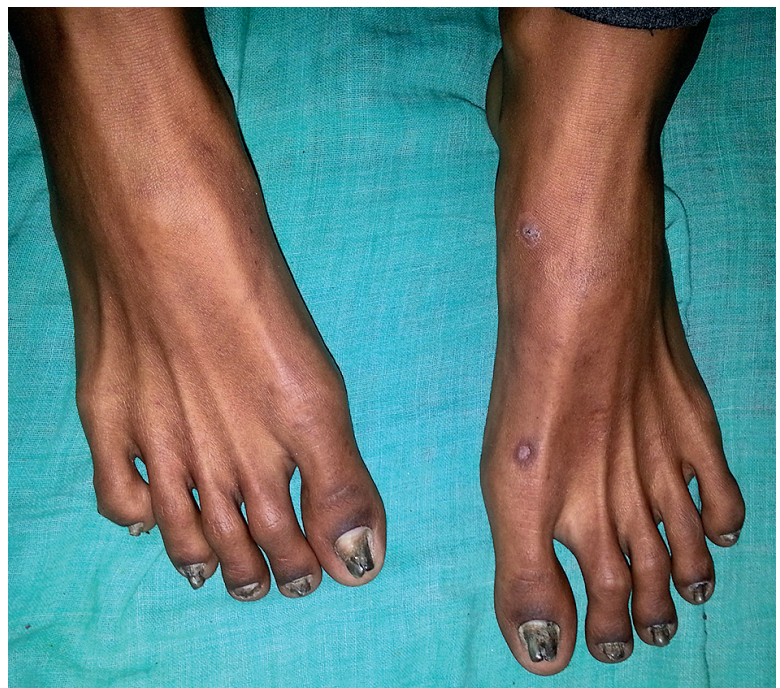

Figure 2. Pincer nails: hyperpigmented pincer nails of the toes with distal dystrophy of both great toes

Rycina 2. Paznokcie pincetowate - przebarwienia paznokci stóp z dystalną dystrofiq obu paluchów 
urea cream was applied under occlusion over the affected nails and subsequently softened nail material was removed. In a 2-month follow-up her systemic complaints, i.e. arthralgia, fever and malaise, resolved, and subungual pain decreased but nail over-curvature did not show improvement. At this point of time, she was lost to further follow-up.

\section{DISCUSSION}

Morphologically there are three clinical types of pincer nail: the "common" pincer nail (trumpet nail deformity), the tile-shaped nail, and the plicated nail. The most frequently seen type is the trumpet nail deformity (which was present in our patient) with the over-curvature increasing proximally to distally along the axis [16]. The hereditary pincer nail is almost always symmetrical [17], whereas acquired pincer nails are not symmetrical. Yellow nail syndrome, hidrotic ectodermal dysplasia and Dowling-Meara type of epidermolysis bullosa simplex can be associated with hereditary type of pincer nail deformity $[3,18]$.

Other than ill-fitting shoes, acquired pincer nails are seen in systemic diseases including Kawasaki disease, renal failure, gastrointestinal malignancy and amyotrophic lateral sclerosis [6-9].

Nail changes are common in association with SLE, ranging from $31 \%$ to $50 \%$ of patients $[19,20]$. Direct immunofluorescence of the proximal nail fold in SLE shows the typical immune deposit pattern of lupus band (LB) at the dermal-epidermal junction [20]. Erythema and telangiectasias of the proximal nail fold are the most frequent changes in SLE. Changes secondary to Raynaud's phenomenon and distal ischemia are also common in SLE. Other findings include prominent nail fold capillaries, vascular infarction, red lunulae, diffuse nail pigmentation and melanonychia [21]. Urowitz et al. found that SLE patients with nail changes tended to have higher incidence of Raynaud's phenomenon and ulcers of the oral mucosae [19]. Pincer nails have only been described three times in association with SLE. Majeski et al. [13] reported pincer nails in a patient with a 4-month history of SLE, who also had oral ulcers and photosensitivity. In another case, reported by Twigg et al. [14], the patient developed pincer nail deformity 12 years after the diagnosis of SLE, and there were no other cutaneous manifestations of SLE. Recently Azevedo et al. reported an SLE patient with class V lupus nephritis who had classic cutaneous, musculoskeletal and psychiatric features of SLE with pincer nail deformity [15]. Interestingly, our patient did not develop any specific cutaneous manifestations of SLE or any signs of hepatitis, despite the high przepisano leczenie doustne dużymi dawkami prednizolonu w dawce początkowej $1 \mathrm{mg} / \mathrm{kg}$ m.c./dobę, którą stopniowo zmniejszano. Leczenie uzupełniono następnie doustną hydroksychlorochiną $\mathrm{w}$ dawce 200 mg/dobę. Oprócz leku przeciwzapalnego w terapii zniekształceń paznokci i dolegliwości bólowych zaaplikowano krem z mocznikiem $20 \%$ pod opatrunkiem okluzyjnym na zajęte chorobą paznokcie. Zmiękczony materiał w obrębie paznokci został następnie usunięty. W trakcie 2-miesięcznej obserwacji objawy układowe (bóle stawów, gorączka i złe samopoczucie) ustąpiły i zmniejszył się ból podpaznokciowy. Nie obserwowano natomiast poprawy pod względem nadmiernego zawijania płytek paznokciowych. Pacjentka nie zgłosiła się do kolejnej kontroli.

\section{DYSKUSJA}

Pod względem kryteriów morfologicznych wyróżnia się trzy typy kliniczne paznokci pincetowatych: typ „pospolity” (paznokcie rurkowate), paznokcie dachówkowate oraz wkręcające. Najczęstszym typem są paznokcie rurkowate (stwierdzone u pacjentki), z zawijaniem narastającym w kierunku od proksymalnego do dystalnego wzdłuż osi paznokcia [16]. W przypadku dziedzicznego podłoża paznokci pincetowanych zmiany niemal zawsze mają układ symetryczny [17], a w przypadku podłoża nabytego - niesymetryczny. Z dziedzicznym typem paznokci pincetowatych mogą być związane inne schorzenia, takie jak zespół żółtych paznokci, dysplazja ektodermalna z zachowaną czynnością gruczołów potowych oraz odmiana Dowlinga-Meary postaci zwykłej pęcherzowego oddzielania się naskórka (epidermolysis bullosa) [3, 18].

Poza nieprawidłowo dopasowanym obuwiem postać nabytą paznokci pincetowatych stwierdza się także w chorobach układowych, m.in. w chorobie Kawasaki, niewydolności nerek, nowotworach złośliwych przewodu pokarmowego oraz stwardnieniu zanikowym bocznym [6-9].

Zmiany obejmujące aparat paznokciowy często obserwuje się w przebiegu SLE - występują u 31-50\% pacjentów $[19,20]$. Bezpośrednie badanie immunofluorescencyjne proksymalnego wału paznokciowego w SLE wykazuje typowe linijne złogi immunologiczne (lupus band) w okolicy połączenia skórno-naskórkowego [20]. Najczęstszymi zmianami towarzyszącymi SLE są rumień i teleangiektazje w obrębie proksymalnego wału paznokciowego. W przebiegu SLE powszechnie występują także zmiany wtórne do objawu Raynauda oraz niedokrwienie dystalne. Inne cechy obejmują powiększenie naczyń włosowatych w obrębie wałów paznokciowych, zawał naczyń krwionośnych, czerwono zabarwione obłączki, rozlane zmiany pigmentacyjne i ciemne zabarwienie paznokci (melanonychię) [21]. W pracy Urowitza i wsp. zaobserwowano zwiększoną częstość 
end-point titers of ANA, anti-dsDNA and positive anti-AMA-M2 and anti-nucleosome antibody. Also there were no signs of renal involvement, as anti-nucleosome antibody signifies renal involvement in SLE and pincer nail has been noted in patients with lupus nephritis [7, 14, 22].

The over-curvature in pincer nail is probably due to an enlarged base of the distal phalanx, where the matrix is firmly attached by collagen fibers. As toenails are markedly curved, the curvature of the proximal (matricial) nail plate segment decreases and consequently increases distally [2]. Majeski et al. suggested the role of vasculitis leading to altered nail keratinization and subsequent fibrous deposits around the distal interphalangeal joints leading to pincer nails [13]. Another possible mechanism of development of pincer nails in renal failure could be due to endothelial dysfunction, impaired microcirculatory function and secondary hyperparathyroidism, while some authors have implicated the role of long-term uremia [7, 23, 24].

The main treatment indications of pincer nails are pain and inflammation. Other indications include interference with wearing footwear and cosmetic embarrassment. Though treating the underlying cause is the definite treatment, other treatment options vary according to the severity and type of over-curvature, possible risk factors, previous history of any treatment, and personal and psychological preferences of both the treating physician and the patient [2]. First, the nail has to be softened using an emollient under occlusion for a few days, or a 10-minute hot foot bath prior to nail clipping can be used. The effective treatment modality was found to be permanent removal of the lateral matrix horns, which is also the simplest, least painful procedure [2]. Zook et al. suggested another effective procedure which aims at flattening the sterile matrix (nail bed) and lateral portions of the germinal matrix $[25,26]$. Mild cases of pincer nail can be treated conservatively, which requires a long treatment period with a high recurrence rate but causes less discomfort to the patient. Meanwhile, patients with severe deformity can be treated with chemical or surgical removal of the lateral matrix horns, and placing a dermal graft under the nail matrix, which provides an excellent long-term treatment outcome but may cause severe discomfort.

\section{CONCLUSIONS}

Pincer nail deformity can be an initial presentation or the only cutaneous sign of SLE in certain patients. As it is multifactorial in origin, it is prudent występowania objawu Raynauda i owrzodzeń błony śluzowej jamy ustnej u pacjentów z SLE ze zmianami paznokciowymi [19]. Istnieją zaledwie trzy doniesienia dotyczące występowania paznokci pincetowatych w SLE. Majeski i wsp. [13] opisali paznokcie pincetowate u pacjenta z rozpoznanym 4 miesiące wcześniej SLE, z towarzyszącymi owrzodzeniami jamy ustnej i nadwrażliwością na światło. W innej pracy, Twigga i wsp. [14], paznokcie pincetowate wystąpiły u pacjenta 12 lat po rozpoznaniu SLE jako jedyny objaw skórny schorzenia. Ostatnio Azevedo i wsp. przedstawili pacjenta z SLE oraz nefropatią toczniową klasy V, u którego stwierdzono klasyczne skórne, mięśniowo-szkieletowe i psychiczne zaburzenia typowe dla SLE, a także paznokcie pincetowate [15]. Co ciekawe, u naszej pacjentki nie wystąpiły żadne swoiste objawy skórne SLE ani objawy zapalenia wątroby pomimo bardzo wysokiego miana przeciwciał ANA, anty-dsDNA oraz dodatnich przeciwciał anty-AMA-M2 i przeciwciał przeciwko nukleosomom. Nie pojawiły się również objawy zajęcia nerek, choć przeciwciała przeciwko nukleosomom są oznaką zajęcia nerek w przebiegu SLE, a paznokcie pincetowate obserwowano u pacjentów $\mathrm{z}$ nefropatią toczniową [7, 14, 22].

Zawijanie się płytek paznokciowych jest prawdopodobnie wynikiem powiększenia podstawy paliczków dystalnych, gdzie macierz jest mocno przytwierdzona włóknami kolagenowymi. Przy znaczącym wygięciu paznokci stóp zmniejsza się krzywizna proksymalnego segmentu płytki paznokciowej przy jednoczesnym przeroście dystalnym [2]. Majeski i wsp. zwrócili uwagę na rolę zapalenia naczyń, które prowadzi do zaburzeń keratynizacji paznokci, a w efekcie do odkładania się włóknistych złogów wokół dystalnych stawów międzypaliczkowych i rozwoju paznokci pincetowatych [13]. Inny potencjalny mechanizm powstawania schorzenia w przebiegu niewydolności nerek polega na zaburzeniu funkcji śródbłonka, upośledzeniu czynności mikrokrążenia i wtórnej nadczynności przytarczyc. Niektórzy autorzy wskazywali także, że schorzenie może być związane z długotrwałą mocznicą [7, 23, 24].

Podstawowym wskazaniem do leczenia paznokci pincetowatych jest obecność dolegliwości bólowych i stanu zapalnego. Inne wskazania obejmują dyskomfort przy noszeniu obuwia oraz względy kosmetyczne. Najważniejsze jest wyeliminowanie pierwotnej przyczyny schorzenia. Stosowane opcje terapeutyczne zależą od rodzaju i stopnia zawinięcia płytki paznokciowej, ewentualnych czynników ryzyka, przebytego leczenia, a także indywidualnych i psychologicznych preferencji [2]. W pierwszej kolejności paznokcie wymagają zmiękczenia przy użyciu emolientu pod opatrunkiem okluzyjnym przez kilka dni. Można również zastosować 10-minutową gorącą kąpiel stóp przed skróceniem paznokci. Stwierdzono skuteczność metody polegającej na 
to evaluate these patients thoroughly to pin-point the underlying etiology. Further in-depth studies are required to elucidate its association with systemic diseases.

\section{CONFLICT OF INTEREST}

The author declares no conflict of interest. trwałym usunięciu bocznych części macierzy paznokcia. Jest to najprostszy i najmniej bolesny dla pacjenta zabieg [2]. Zook i wsp. zaproponowali inną skuteczną metodę, która polega na spłaszczaniu macierzy paznokcia $[25,26]$. W łagodnych przypadkach paznokci pincetowatych stosuje się leczenie zachowawcze. Okres leczenia jest długi, a wskaźnik nawrotów wysoki, jednak jest to metoda, która wywołuje najmniejszy dyskomfort pacjenta. U pacjentów z nasiloną deformacją paznokci można usunąć chemicznie lub chirurgicznie boczne części macierzy oraz umieścić przeszczep skóry pod macierzą paznokcia. Metoda ta zapewnia doskonałą długoterminową skuteczność, jednak może się wiązać ze znaczącym dyskomfortem dla pacjenta.

\section{WNIOSKI}

Paznokcie pincetowate mogą być początkowym lub jedynym skórnym objawem SLE u niektórych pacjentów. Schorzenie to ma wieloczynnikowe podłoże, dlatego uzasadnione jest przeprowadzenie szczegółowej diagnostyki w celu identyfikacji jego etiologii. Niezbędne są również dodatkowe badania nad zależnością między występowaniem tych zmian paznokciowych a chorobami układowymi.

\section{KONFLIKT INTERESÓW}

Autor deklaruje brak konfliktu interesów.

\section{References}

Piśmiennictwo

1. Cornelius C.E. 3rd, Shelley W.B.: Pincer nail syndrome. Arch Surg 1968, 96, 321-322.

2. Baran R., Haneke E., Richert B.: Pincer nails: definition and surgical treatment. Dermatol Surg 2001, 27, 261-266.

3. Baran R., Dawber R.P.R., Tosti A., Haneke E.: A text atlas of nail disorders. Martin Dunitz, London, 1996, 29.

4. Baran R., Broutard J.C.: Epidermoid cyst of the thumb presenting as pincer nail. J Am Acad Dermatol 1988, 19, 143-144.

5. Higashi N.: Pincer nail due to tinea unguium. Hifu 1990, 32, 40-44.

6. Vanderhooft S.L., Vanderhooft J.E.: Pincer nail deformity after Kawasaki's disease. J Am Acad Dermatol 1999, 41, 341-342.

7. Kirkland C.R., Sheth P.: Acquired pincer nail deformity associated with end stage renal disease secondary to diabetes. Dermatol Online J 2009, 15, 17-19.

8. Jemec G.B.E., Thomsen K.: Pincer nails and alopecia as markers of gastrointestinal malignancy. J Dermatol 1997, 24, 479-481.

9. Fujita Y., Fujita T.: Pincer nail deformity in a patient with amyotrophic lateral sclerosis. Neurol Int 2014, 6, 5716.

10. Hwang S.M., Lee S.H., Ahn S.K.: Pincer nail deformity and pseudo-Kaposi's sarcoma: complications of an artificial arteriovenous fistula for haemodialysis. Br J Dermatol 1999, 141, 1129-1132.

11. Bureau H., Baran R., Haneke E.: Nail surgery and traumatic abnormalities. In: Diseases of the Nails and Their Management. R. Baran, R.P.R. Dawber (eds.). Blackwell, Oxford, 1984, 347-402.

12. Greiner D., Schöfer H., Milbradt R.: Reversible transverse overcurvature of the nails (pincer nails) after treatment with a beta-blocker. J Am Acad Dermatol 1998, 39, 486-487.

13. Majeski C., Richie B., Giuffre M., Lauzon G.: Pincer nail deformity associated with systemic lupus erythematosus. J Cutan Med Surg 2005, 9, 2-5.

14. Twigg E.V., Weitz N.A., Scher R.K., Grossman M.E.: Pincer nails in a patient with systemic lupus erythematosus and lupus nephritis: a case report. JAAD Case Rep 2016, 2, 233-235.

15. Azevedo T.H.V., Neiva C.L.S., Consoli R.V., Couto A.C.D., Dias A.F.M.P., Souza E.J.R.: Pincer nail in a lupus patient. Lupus 2017 Jan 1, 961203317694258.

16. Baran R.: Pincer and trumpet nails. Arch Dermatol 1974, 110, 639-640.

17. Chapman R.S.: Overcurvature of the nails - an inherited disorder. Br J Dermatol 1973, 89, 317-318.

18. Kitajima Y., Jokura Y., Yaoita H.: Epidermolysis bullosa simplex, Dowling-Meara type. A report of two cases with different types of tonofilament clumping. Br J Dermatol 1993, 128, 79-85.

19. Urowitz M.B., Gladman D.D., Chalmers A., Ogryzlo M.A.: Nail lesions in systemic lupus erythematosus. J Rheumatol 1978, $5,441-447$ 
20. Elmansour I., Chiheb S., Benchikhi H.: Nail changes in connective tissue diseases: a study of 39 cases. Pan Afr Med J 2014, $18,150$.

21. Lawry M., Daniel III C.R.: Nails in systemic disease. In: Nails - Diagnosis. Therapy. Surgery. $3^{\text {rd }}$ edn. R.K. Scher, C.R. Daniel (eds.). Saunders (Elsevier), Philadelphia, 2005. 147-169.

22. Min D.J., Kim S.J., Park S.H., Seo Y.I., Kang H.J., Kim W.U., et al.: Anti-nucleosome antibody: significance in lupus patients lacking anti-double-stranded DNA antibody. Clin Exp Rheumatol 2002, 20, 13-18.

23. Dyachenko P., Monselise A., Shustak A., Ziv M., Rozenman D.: Nail disorders in patients with chronic renal failure and undergoing haemodialysis treatment: a case control study. J Eur Acad Dermatol Venereol 2007, 21, 340-344.

24. Stewart J., Kohen A., Brouder D., Rahim F., Adler S., Garrick R., et al.: Noninvasive interrogation of microvasculature for signs of endothelial dysfunction in patients with chronic renal failure. Am J Physiol Heart Circ Physiol 2004, 87, H2687-H2696.

25. Brown R.E., Zook E.G., Williams J.: Correction of pincer-nail deformity using dermal grafting. Plast Reconstr Surg 2000, 105, 1658-1661.

26. Zook E.G., Baran R., Haneke E., Dawber R.P.R.: Nails surgery and traumatic abnormalities. In: Nail Diseases and Their Management. $3^{\text {rd }}$ edn. R. Baran, R.P.R. Dawber, D. DeBerker, E. Haneke, A. Tosti (eds.). Blackwell, Oxford, 2001, 435-514.

Received: 6.03 .2017

Accepted: 11.06 .2017

Otrzymano: 6.03.2017 r.

Zaakceptowano: $11.06 .2017 \mathrm{r}$

How to cite this article

Pawar M.K.: Pincer nails: an initial and isolated cutaneous manifestation of systemic lupus erythematosus. Dermatol Rev/Przegl Dermatol 2017, 104, 337-343. DOI: https://doi.org/10.5114/dr.2017.68781. 